\title{
Operowanie językiem w poszukiwaniu sensu oryginału
}

\section{Language operation in search of the original sense}

\author{
Lidia Tanuszewska \\ Wydział Filologiczny im. Blaže Koneskiego, Uniwersytet św. św. Cyryla i Metodego, \\ ul. Simče Nastevski nr 32a, 1000 Skopje, Macedonia; \\ e-mail: lidkapol@yahoo.com
}

\begin{abstract}
This article is about the translation as a process which changes the way of thinking in the other language, the one in which we translate. In order to make that text understandable for readers, the translator needs to make some changes in the original text, i.e. to manipulate with the language, so that the translation will transfer the same meaning and sense of the original one. Paraphrase is one of the strategies that is presented in this work.
\end{abstract}

Keywords: translation; sense; meaning; change; paraphrase.

W połowie lat siedemdziesiątych uczeni zajmujący się teorią przekładu podjęli inycjatywę, żeby przekładoznawstwo stało się nauką zintegrowaną oraz interdyscyplinarną. Dziś przekład w ramach dialogu interdyscyplinarnego rozumiany jest jako szeroko pojęty przedmiot, ale i proces. Semiotyka zakłada, że możliwe jest przetłumaczenie znaczenia znaku językowego na inny znak alternatywny, a w związku z tym - jeden z przekładów znaku językowego to przekład międzyjęzykowy, stanowiący interpretację znaków językowych za pomocą znaków innego języka. W tym miejscu należy podkreślić, iż duży wpływ na przekładoznawstwo w jego późniejszym rozwoju wywarła lingwistyka tekstu. Teoretycy przekładu podkreślają rangę opisu tekstu tłumaczenia, zajmują się jednostkami większymi niż samo zdanie, wypowiedzenie, czyli wypowiedziami - tekstami, jednocześnie zwracają uwagę na aspekty pozatekstualne przekładu.

W latach osiemdziesiątych wyodrębniła się szkoła tzw. „manipulistów”, której przedmiotem zainteresowania był tekst języka docelowego, a nie oryginału. Nazwano ją ,szkołą manipulacyjną” - choć nazwa ta może budzić pewne wątpliwości, jednak z literaturoznawczego ${ }^{1}$ punktu widzienia każdy przekład implikuje

\footnotetext{
${ }^{1}$ W ujęciu językoznawczym manipulację należy rozumieć nieco inaczej.
} 
pewien stopień manipulacji tekstem oryginału, gdyż realizuje jakiś określony cel. Komunikologia zakłada, iż celem przekładu jest przekazanie treści oryginału obcojęzycznemu czytelnikowi w procesie komunikacji.

Natomiast kolejne pokolenie translatologów zwraca uwagę na kulturologiczny aspekt przekładu, rozumianego jako ekwiwalent przekładowy. Dodać należy, że według pierwszych teoretyków przekładu ekwiwalent powinien zawierać takie składniki i struktury z własnego języka, które wywołują identyczną reakcję u czytelnika jak ta, którą wywoływał oryginał u czytelników będących rodzimymi użytkownikami języka. Bliscy takiemu stanowisku są Eugene Nida i Olgierd Wojtasiewicz. Po raz pierwszy w rozwoju dyscypliny zwraca się uwagę na odbiorcę tekstu. Zenon Klemensiewicz pisał przed laty :

Oryginał powinno się zrozumieć jako system, a nie sumę składników, jako całość organiczną, a nie jako zbiór mechaniczny składników. Zadaniem przekładu nie jest reprodukcja albo przekształcenie składników i struktur oryginału, ale wprowadzenie takich składników i struktur z własnego języka, które będą substytutami i ekwiwalentami z taką samą wartością funkcjonalną i efektywnością (cyt. za: Levi 1982: 37).

Tymczasem Eugene Nida stwierdził, że ,przekład zły to taki, który czytelnik może interpretować dowolnie, dobry zaś to taki, który wywołuje reakcję zaplanowaną przez oryginał i potwierdzoną jego autorytetem" (cyt. za: Bukowski, Heydel red. 2009: 10). Podobnie według Olgierda Wojtasiewicza „operacja tłumaczenia polega na sformułowaniu w pewnym języku odpowiednika wypowiedzenia sformułowanego uprzednio w innym języku" (1996: 12), przy czym przez odpowiednik (inaczej ekwiwalent) badacz rozumie tekst wywołujący w pewnym języku taką samą reakcję u odbiorcy, jaką wywołał u niego tekst wcześniej wyrażony w innym języku.

Należy podkreślić, iż odpowiednika przekładowego nie zawsze można i powinno się szukać w słowniku dwujęzycznym. Istnieje tzw. mit słownika, czyli przekonanie, że słownik daje nam ekwiwalenty przekładowe wszystkich jednostek leksykalnych. Takie stanowisko jest niemożliwe do utrzymania, ponieważ słowniki opisują językową rzeczywistość tylko w kategoriach statystycznych. Tak samo nieprawdziwe jest przekonanie, że wszystkie znaczenia danego leksemu są zawarte w słowach, nie bierze się przecież pod uwagę wszystkich potencjalnych uwarunkowań kontekstualnych słów. Jakiś wyraz może się znaleźć w przeróżnych nietypowych sytuacjach tekstualnych, ale leksykograf musi dokonać pewnego wyboru, gdyż słownik określonego języka nie może podawać wszystkich znaczeń. Typowym przykładem ekwiwalentu słownikowego, który może doprowadzić do błędnego tłumaczenia, jest poniższy fragment (przykłady zaczerpnięto z istniejących przekładów polskiej literatury pięknej na język macedoński; por. spis skrótów oraz wykorzystanych źródeł zamieszczony na końcu artykułu): 
pol. Sypkie, ptynne, skaliste, rozplomienione i lotne,

połacie nieba, okruszyny nieba. (,Niebo” WSZIn)

тас. Сипливи, течни, карпести,

распламтени и гасовити

простори на небото, трошки од небото. (ВШК, с. 135)

Słownik polsko-macedoński jako odpowiednik wyrazu połać rzeczywiście podaje простор, пространство albo територија ('przestrzeń, terytorium'), ale tu akurat chodzi o 'część przestrzeni, która może być ograniczona pewnymi krawędziami'. Lepszym rozwiązaniem byłby wolniejszy przekład, w którym można by użyć, na przykład: „крајчиґа небо” albo „nарчиња небо” (skrawki albo kawałki nieba).

$\mathrm{Z}$ podobną sytuacją błędnego użycia analogicznej formy w języku obcym mamy do czynienia w kolejnym przykładzie, gdyż słownikowy odpowiednik konektora w języku macedońskim nie funkcjonuje jako konektor zdań wyrażających wykluczenie, tylko przeciwstawność:

pol. Nawet nie większość wszystkich, ale mniejszość. („Niektórzy lubią poezję” WSZA, s. 781)

тас. Дури не мнозинството од сите, но малиинството. (ВШК, с. 137)

W przywołanym przekładzie powinnien był przeważyć kontekst nad prostym odwzorowaniem form, w związku z tym - zgodnie $\mathrm{z}$ regułami składni języka macedońskiego - należy przetłumaczyć polskie ale na odpowiedni dla tego kontekstu konektor туку.

Jeszcze bardziej nieadekwatny przekład uzyskuje się, jeżeli zastosuje się dosłowne tłumaczenie frazeologizmów, jak w poniższym przykładzie:

pol. Nic darowane, wszystko pożyczone.

Tone w dlugach po uszy. („Nic darowane” WSZA, s. 784)

тас. Ништо не е подарено, само позајмено.

Во долгови тонам до уши. (ВШК, с. 161)

Należy podkreślić fakt, iż w języku macedońskim nie tonie się ,„po uszy”, lecz „do gardła”. Dosłownie przetłumaczony polski frazeologizm nie funkcjonuje jako taki w standardowym języku macedońskim i czyni śmiesznymi wiersze, które nie mają takiego charakteru.

Wydaje się, że we wszystkich wyżej podanych przykładach udało się znaleźć odpowiedniki funkcjonalne, ale stopień efektywności wywołanych przez nie reakcji u odbiorcy nie jest taki sam jak w wypadku oryginału. Uważamy, że strategie translatologiczne, w których wykorzystano inny skład leksykalny w celu przeniesienia sensu oryginału, usprawiedliwiają tego rodzaju zabieg odstępowania od dosłownego znaczenia, gdyż mają na celu przybliżenie treści przekładanego tekstu. 
Za wolny przekład możemy uważać parafrazę, którą najczęściej określa się jako „powiedzenie czegoś w inny sposób, inaczej”, w przekładzie można też zastosować to opisowe wyjaśnienie w celu lepszego zrozumienia przez czytelnika danego fragmentu tekstu. W językoznawczym ujęciu parafraza przedstawia przekształcenie synonimiczne, tj. zastępowanie jednego wyrazu innym wyrazem, czyli wyrażanie tej samej treści innymi strukturalnymi (powierzchniowymi) środkami językowymi. Dotyczy to przede wszystkim zmiany w tym samym języku, ale też odnosi się do relacji między oryginałem a przekładem. Językoznawstwo abstrahuje przy tym od aspektów semantycznych i nie zwraca uwagi na to, że parafraza często pociąga za sobą zmianę znaczenia całego zdania. Natomiast przekładoznawstwo zajmuje się właśnie tą zmianą znaczenia, a mianowicie zachowaniem sensu całego tekstu wobec zmiany jednostek składniowych i struktury zdania.

Parafraza jest często interpretacją oryginalnego tekstu. Teoria interpretacji, czyli hermeneutyka, też koncentruje się na rozumieniu obcego sensu, więc jak to powiedział Johann Gottfried Herder - „dobry tłumacz powinien też być dobrym interpretatorem". Parafraza jest właściwym zabiegiem w przekładzie, zwłaszcza w tych wypadkach, kiedy nie traci się przez nią ważnych informacji $\mathrm{z}$ tekstu oryginału, a także kiedy chodzi o stylistyczne przekształcenie tekstu, na przykład:

pol. A rosło przygnębienie, spowodowane nieustanna huśtawka: Lukasz to widział lepiej i serce otwierat nadziei, to gorzej... (GHGB, s. 75)

mac. А потиштеноста се зголемуваше, предизвикана од постојаното менуваве на состојбата: Лукаи, де, гледаше подобро и срието му се отвораме за надеж, де, полошо... (ГХГБ, с. 67)

Przedmiotem parafrazowania jest tutaj polski leksem huśtawka, któremu w podstawowym jego znaczeniu odpowiada macedoński rzeczownik клацкалка. Jednak w przekładzie użyto parafrazy „zmiana stanu”, ponieważ tłumacz uznał, że stylistycznie bardziej odpowiada to znaczeniu całego polskiego tekstu, a gdyby użył tylko odpowiednika leksykalnego, byłoby niejasne dla macedońskiego odbiorcy, że chodzi o stan zdrowia.

W poniższym przykładzie mamy zaś polski frazeologizm przetłumaczony za pomocą słów, które nie są prostymi odpowiednikami, ale tworzą również frazeologizm w języku macedońskim:

pol. - Różne tam narcotica, venena, wolna amerykanka - co? (SLS, s. 79)

тас. - Разни наркотичи, венена, слободен стил - нели? (СЛС, с. 63)

Dosłowne tłumaczenie wolnej amerykanki byłoby niejasne dla macedońskiego czytelnika. 
Przytaczam tutaj jeszcze jeden podobny przykład:

pol. Genowefa nosita go na rẹkach calymi nocami, tam i z powrotem, po kuchni, po pokoju. (OTP, s. 71)

mac. Геновева го држеме в раче по иели ноќи, думкајќи го ваму-таму, низ кујната, низ собата. (ОТП, с. 87)

Zacytowane polskie zdanie w dosłownym przekładzie na język macedoński brzmiałoby: „Genowefa trzymała go na rękach całymi nocami, kołysząc go tam i z powrotem, po kuchni, po pokoju". Należy zauważyć, iż czasownik думка odnosi się tylko do kołysania niemowlęcia w celu jego uśpienia, aby zatem oddać sens tej wypowiedzi, trochę zmieniono konstrukcję zdania i kolejność wyrazów, tak by je dopasować do systemu składniowego języka macedońskiego. Specyficzny wyraz macedoński charakterystyczny dla mowy potocznej przybliża tekst przekładowy czytelnikom docelowym.

Parafrazowanie albo wolny przekład jest właściwym zabiegiem tłumaczeniowym i w takich wypadkach, kiedy nie istnieją środki gramatyczne i leksykalne, by przenieść tę samą strukturę z jednego języka do drugiego. Taki zabieg ,pośredniego" tłumaczenia, gdy tłumacz zamienia jedną klasę wyrazów na drugą, nazywa się transpozycją. W przekładach z języka polskiego na język macedoński najczęściej pojawia się transpozycja przymiotnika na jakąś inną część mowy. Wydaje się, że język polski jest bogatszy w przymiotniki, ponadto słowotwórstwo polskich przymiotników jest regularniejsze niż w języku macedońskim. Często się zdarza, że nie istnieje odpowiednik leksykalny polskiego przymiotnika w języku macedońskim albo istnieje, ale nie ma szerszego użycia $-\mathrm{z}$ taką sytuacją mamy do czynienia w poniższym przykładzie:

pol. Żyrardów byt czerwony i ceglany. (ASJ, s. 9)

mас. Жирардув беше ирвен, изграден од тули. (АСП, с. 85)

W macedońskim przekładzie brak odpowiedniego przymiotnika zmusza tłumacza do manipulacji językiem i wykorzystania wyrazów należących do innych części mowy, które jednak będą zawierać odpowiednie znaczenia, pozwalające oddać sens brakującego przymiotnika. W analizowanym wypadku przymiotnik ceglany zastąpiła syntagma: zbudowany z cegły.

W języku polskim imiesłów przymiotnikowy czynny często pełni w zdaniu funkcję przymiotnika. Ponieważ w języku macedońskim nie istnieje taka forma gramatyczna, imiesłów automatycznie tłumaczy się za pomocą zdania względnego, na przykład polski imiesłów stojąca oddaje konstrukacja „która stała obok niego": 
pol. Innym wzrokiem spojrzat na stojaca obok niego Urszule. (GHGB, s. 72)

mac. Со поинаков поглед ја погледна Уршула, која стоеше до него. (ГХГБ, с. 64)

$\mathrm{Na}$ koniec tych rozważań należy jednak stwierdzić, że czasami mają rację zwolennicy dosłownego tłumaczenia, ponieważ, jak powiedział Vladimir Nabokov: „wszystkie wolne tłumaczenia są uproszczeniami, które trywializują tekst oryginału" (cyt. za: Hejwowski 2004: 24). Uważam, że uproszczenia są czasami dobrym rozwiązaniem, jeżeli chodzi o trudny i skomplikowany tekst oryginału, ale często zdarza się, że tłumacz nie docenia wiedzy i inteligencji odbiorcy docelowego, więc przez zastosowanie uproszczenia w przekładzie oryginału traci jakąś ważną informację albo przekształca tekst w taki sposób, iż ginie zamierzony styl autora oryginału. Ilustracją tego zjawiska może być następujący przykład:

pol. ...obaj wydobyci z rozdolu Powórnej, widoczni, i niecenzuralność moja z nim wystawiona na sztych dalekiego widzenia. (WGP, s. 43)

тас. ...двајиата извлечени од удолнината на Поворна, видливи оддалеку како чел. (ВГП, c. 44)

Uproszczenie po polsku brzmiałoby: „,widoczni z daleka jako cel/metę”. Traci się przy tym informacje o tym, że niecenzuralność narratora (jego stosunek do chłopca, czyli brak samocenzury) jest wystawiona na niebezpieczeństwo dalekiego widzenia (że może być odkryta, zauważona przez kogoś, kto patrzy na nich $\mathrm{z}$ daleka, prawdopodbnie przez lunetę). A taki przekład nadaje już całkiem inny sens całemu tekstowi.

Teoretyzowaniem na temat przekładu zajmowano się od dawna. W X wieku święty Konstantyn, zwany Cyrylem, napisał Słowo o przekładzie jako przedmowę do pierwszego tekstu z Biblii przetłumaczonego na język staro-cerkiewno-słowiański, który jest bezpośrednim przodkiem współczesnego języka macedońskiego. W tym Słowie powiedział, że „tłumacząc dowolnie dane zdanie, można stanąć przed wielkim tłumaczeniem (interpretacją)" (Велев 2008: 28). Tak jak tłumaczenie dosłowne może być niewłaściwe, również parafraza może być sygnałem niezrozumienia oryginału - chociaż zamiarem tłumacza w obu wypadkach było wyjaśnienie oryginału, przybliżenie treści tekstu docelowemu czytelnikowi, na przykład:

pol. Ale mnie, któremu z tym chłopcem Bóg naraz zmieszat sie z kobietami w jakimś qui pro quo groteskowym i prawie pijanym, to jego ,za młody" zabrzmiało dziwnie, ostrzegawczo. (WGP, s. 49)

mac. Но мене, кој со тоа момченце и со жените Господ одеднаш ме помеша во некое гротескно и речиси пијано qиі рго qио, тоа негово "премлад" ми зазвучи чудно, предупредувачки. (ВГП, с. 49) 
Niejasność tekstu przekładu wynika z pomieszania przez tłumacza tego, „kto z kim”, tzn. Boga zamienił z pierwszą osobą, co sprawiło, że po macedońsku polski tekst oddał w następujący sposób: „mnie, który z tym chłopcem i z kobietami Bóg zmieszał w jakimś qui pro quo...".

Na zakończenie niniejszych rozważań można stwierdzić, że wszystkie przywołane tu przykłady przekładu tekstów polskich na język macedoński są wynikiem nieudanych prób znalezienia środków językowych dokonywanych przez thumacza w jego staraniach, by za pomocą odpowiedniego ekwiwalentu przenieść sens polskiego oryginału. Okazuje się, że błędy w tłumaczeniu wynikają z wielu przyczyn, m.in. z niezrozumienia polskiego tekstu oraz pochopnego tłumaczenia metodą ,słowo po słowie”. Natomiast różnice między językami powodują konieczność stosowania peryfraz, różnego rodzaju uproszczeń i odbiegania od dosłowności, co często powoduje jednak utratę jakiejś części ukrytych sensów oryginału.

\section{ROZWIĄZANIE SKRóTów}

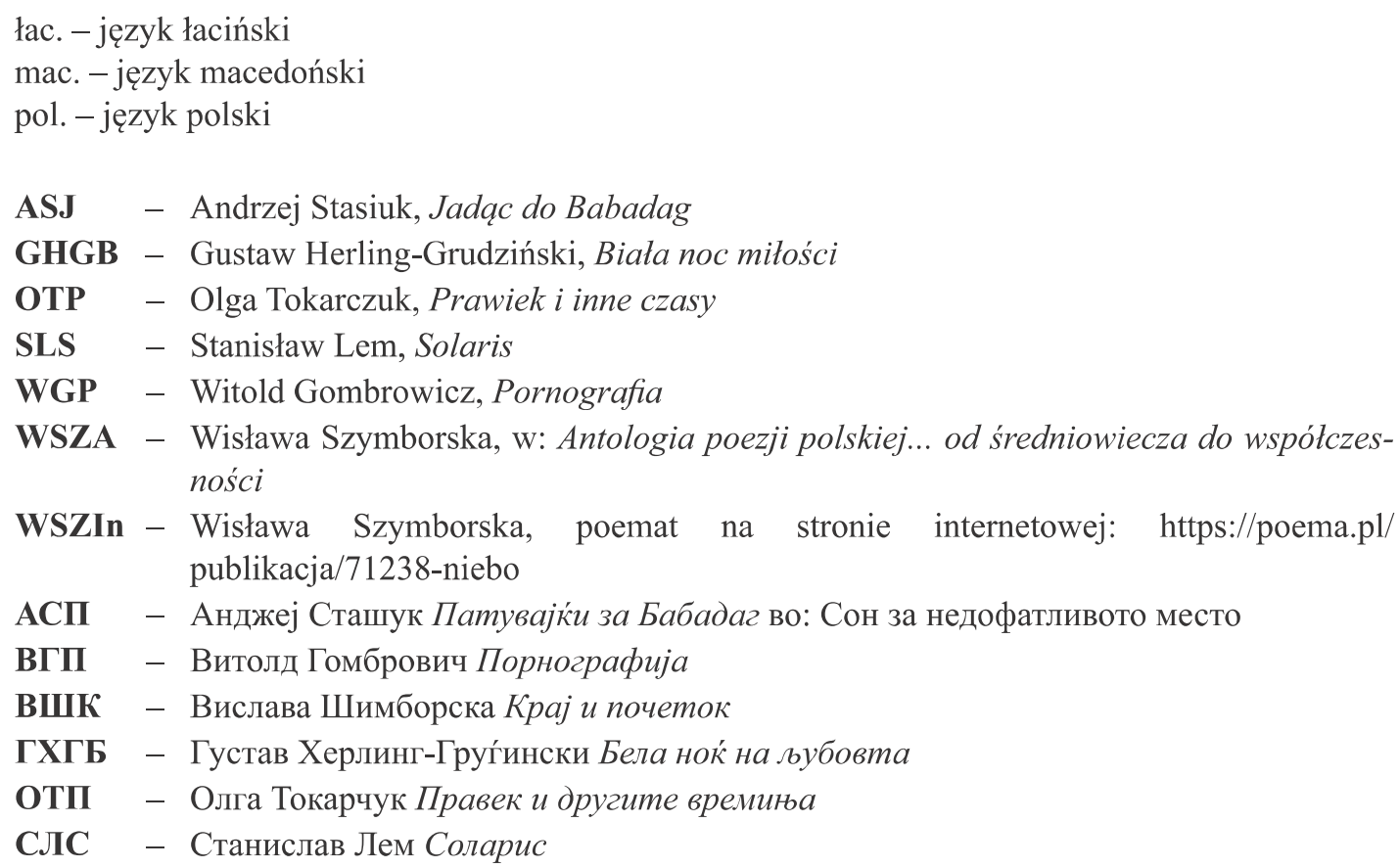

\section{WYKAZ ŹRÓDEE}

Gombrowicz W., Pornografia, Kraków 1987.

Grzybowski J., Antologia poezji polskiej... od średniowiecza do współczesności, Katowice 2007.

Herling-Grudziński G., Biała noc miłości, Warszawa 1999.

Lem S., Solaris, Kraków 2002. 
Stasiuk A., Jadac do Babadag, Wołowiec 2004.

Tokarczuk O., Prawiek i inne czasy, Wałbrzych 2000.

Гомбрович В., Порнографија, прев. Дејан Геговски, Скопје 2000.

Лем С., Соларис, прев. Григори Поповски, Скопје 1989.

Токарчук О., Правек и другите времиъа, прев. Лидија Танушевска, Скопје 2007.

Фрагменти од современата полска проза/Олга Токарчук, Стефан Хвин, Анджеј Сташук, Сон за недофатливото место, прев. Полонистичка преведувачка лабораторија при Филолошкиот факултет „Блаже Конески”, под менторство на проф. д-р Милица Миркуловска, Скопје 2006.

Херлинг-Груѓињски Г., Бела ноќ на љубовта, прев. Лидија Танушевска, Скопје 2006.

Шимборска В., Крај и почеток, избор и прев. Петар Наковски, Скопје 1996.

\section{Bibliografia}

Bukowski P., Heydel M. (red.), 2009, Wspótczesne teorie przekładu. Antologia, Kraków. Hejwowski K., 2004, Kognitywno-komunikacyjna teoria przekładu, Warszawa.

Levi J., 1982, Umjetnost prevođenja, prev. Bogdan L. Dabić, Sarajevo.

Wojtasiewicz O., 1996, Wstęp do teorii thumaczenia, Warszawa.

Велев И., 2008, Македонска книжевност IX-XVII век, Битола. 